\title{
Empowerment through Energy? Impact of Electricity on Care Work Practices and Gender Relations
}

\author{
Karina Standal* and Tanja Winther* \\ * Centre for Development and the Environment, University of Oslo, Norway
}

\begin{abstract}
Electricity provides a range of desirable services such as electric light and the use of mobile phones and is regarded as a conditional factor for economic growth. Gender equality and women's empowerment are also promoted as a key to development on the international agenda. However, relatively little is known about how the advent of electricity in new contexts affects gender relations. The present analysis of electricity's impact on gender relations engages with the concepts of care work and empowerment. Based on two ethnographic case studies in rural communities in Uttar Pradesh, India, and Bamiyan, Afghanistan, we examine how and to what extent the introduction of electricity affected women's care work practices and empowerment - and potentially transformed gender relations. We also draw on our own empirical material from other parts of India (West Bengal and Jharkhand). We find that electricity affected everyday life in terms of providing important resources and enhancing women's opportunities to perform their expected role as care workers more efficiently and in a qualitatively better way. The women appreciated this positive effect of electricity in their everyday lives. However, we argue that in India, electricity at the same time reinforced structures of gender inequality such as patriarchy and dowry practices, and we trace this tendency to the conceptualisation of women as care workers in combination with conventional, gender 'neutral' electricity interventions. In contrast, there are signs that women's status increased in the Afghanistan case, which we link to the unusual inclusion of women engineers in the electricity supply.
\end{abstract}

Keywords: Electricity, Gender relations, Empowerment, Care work, India, Afghanistan

Word count: 8553

Karina Standal (CA): Centre for Development and the Environment, University of Oslo, Norway, PO Box 1116 Blindern, 0317 Oslo.22858993/karina.standal@sum.uio.no

Tanja Winther: Centre for Development and the Environment, University of Oslo, Norway, PO Box 1116 Blindern, 0317 Oslo. 22858915 /tanja.winther@sum.uio.no 


\section{Introduction}

Access to electricity is denoted as a universal goal, ${ }^{1}$ which is good news to the 1.3 billion people who currently do not have access. Electricity provides a range of desirable services such as electric light and the use of mobile phones and is regarded as a conditional factor for economic growth, educational opportunities and health benefits. Gender equality and women's empowerment are also promoted as a key to development on the international agenda. However, relatively little is known about how the advent of electricity in new contexts affects gender relations. Based on two ethnographic case-studies from rural communities in Uttar Pradesh, India, and Bamiyan, Afghanistan, we examine how and to what extent the introduction of solar electricity affected women's care work practices and empowerment - and potentially transformed gender relations. ${ }^{2}$ We also draw on our own empirical material from West Bengal and Jharkhand in India.

The present analysis of electricity's impact on gender relations engages with the concepts of care work and empowerment. Care work is interlinked with gender relations through its association with '(unwaged) women's work' such as rearing children, tending livestock, cooking and cleaning (Sharma 1986). Care work has been analysed from a 'devaluation perspective', which argues that care work, unlike men's paid work, tends to be considered of less value since it is linked to the private sphere and to women. The 'public good framework' follows this account of why care work tends to be devaluated, and focuses on the public benefits of care work beyond those of immediate recipients. Here it is argued that care work is necessary for the functioning of capitalist societies and that there is a need to make this link visible in order to give care work the (economic) appreciation it deserves (England 2005: 382-385). In the case of rural women's energy responsibilities, visualising the link between care work and public good is of outmost importance, because the health consequences of not having access to modern energy literally take lives.

Empowerment describes and encapsulates the process in which individuals, groups or societies move from being marginalised through poverty, ethnicity, gender or other discriminating relations and markers to a state of equality. According to Friedman (1992:33) three types of power - social, political and psychological - are needed for marginalised groups to become empowered and control their own development. Social power is contingent on access to resources such as supportive life space, means of production and financial

\footnotetext{
${ }^{1}$ Sustainable Development Goal \#7 .Ensure access to affordable, reliable, sustainable and modern energy for all.

2 The data material for the case-studies are gathered by Karina Standal in relation to the PhD project: The Impact of Solar Energy on Rural Women in India, Centre for Development and the Environment, University of Oslo.
} 
resources, information, skills, surplus time and participation in social organisations. Political power is understood by Friedmann as access to decision-making processes. The notion of psychological power reflects the third dimension of empowerment which concerns the development of individual human beings and their 'sense of potency' (ibid). Psychological power is thus gained through confidence and awareness of one's possibilities.

Kabeer's (2001) framework of empowerment draws on Sen (1985), and offers a perspective of empowerment that involves 'the expansion in people's ability to make strategic life choices in a context where this ability was previously denied to them' (Kabeer 1999: 437). This process requires changes in three interconnected dimensions; resources, agency and achievements (ibid.), where resources and agency have similarities with Friedmann's notions of social and political power, and achievements are the outcome of choices. ${ }^{3}$ Gender equality thus concerns women and men's equal access to resources and power to influence decisions, and empowerment is the process through which this state is achieved. Resources have human, social and material aspects and include both short term opportunities and long term assets referred to as endowments (World Bank 2011:4). Access to endowments condition people's immediate 'opportunities', both in the economic sense of generating income (ibid.) and for handling life in general, for example through time management and having access to information. Kabeer's second dimension 'agency' concerns people's degree of influence on issues that concern them. Thirdly, 'achievements' are the impact of a given measure, and here we distinguish between 'immediate outcomes' which denote outcomes that affect people's opportunities (e.g. enabling new employment, access to light and time saved on drudgery), and the long term 'social impact' which concerns potential changes in people's access to endowments, their possibility to make strategic life choices, and thereby power relations. ${ }^{1}$

In the present treatment of the impact of electricity on women's empowerment and gender relations, we account for men and women's roles and responsibilities, decision making power and access to relevant resources. Furthermore, we examine the gendered patterns of electricity use in everyday life and care work. The objective is to explore to what extent and how electricity empowered women in the selected contexts. We do not provide a detailed analysis of the process of electrification (see Winther 2008 and 2014 for treatments of this aspect).

The cases under study reflect the situation of many rural societies in South Asia which have a patriarchal setting where women and young have lower status than men, and which

\footnotetext{
3 Following Kabeer (2001) resources include material, human and social resources acquired through social relationships, market, state and community. Access to resources does not only concern influence over allocation of current resources, but also future claims and expectations which are reflected in norms of distribution.
} 
are informed by values that see women's main accomplishment in life to be married and have children, and where control over women's bodies and reproduction is linked to family honor (Standal 2010:92). Moreover, this is coupled with the fact that women in the rural South tend to have the main responsibility for servicing the traditional energy needs of their families and other care work. In this paper we examine how women's status, access to resources, and their power to decide and make strategic life choices become affected with the advent of modern energy forms such as electricity.

\section{Methods}

The empirical data on women's care work practices used in this article is based on qualitative semi-structured interviews and observation from fieldwork conducted in Uttar Pradesh, India, in 2012 and 2015, and in Bamiyan, Afghanistan in 2007. The material is based on 32 interviews with villagers: 15 interviews in Uttar Pradesh (2 villages) and 17 in Bamiyan (4 villages). 4 The interviews were conducted with women and men, and the topic of care work mainly derived from conversations with women informants because care work is their main responsibility. 5 Additional interviews were also conducted with 12 operators, 8 solar engineers, 4 village committees and representatives of local NGOs, and Norwegian institutions involved in the implementation of the development projects.

This paper draws attention to the women's experiences with solar electricity (photo voltaic) and their access to and uses thereof. Through a comparative analysis of the ethnographic material we will treat the women-energy nexus both at the level of meaning, following Geertz's (1973) 'thick description' and at the same time provide a discussion of how electricity projects might impact women in rural South Asian contexts. To these ends we also draw on our own ethnographic material from other contexts in South Asia, namely West Bengal and Jharkhand in India.

\footnotetext{
${ }^{4}$ The interviews in Uttar Pradesh, India, were conducted in Narwara and Rampura villages and the interviews in Bamiyan, Afghanistan, were conducted in Habashi, Pirdad, Ladu and Jarukashan villages. For anonymity reasons we will only refer to Uttar Pradesh and Bamiyan unless a distinctive feature of a village that is highlighted.

${ }^{5}$ All informants gave their consent to participate in the research, but to safeguard their anonymity any names are fictional.
} 


\section{Solar based village electrification in Uttar Pradesh and Bamiyan}

The case study villages in Uttar Pradesh are located in the semi-arid Bundelkhand region and are small and lie in areas with poor roads, limited water resources and no connection to the central electricity grid. Many of the households own land and base their living on subsistence agriculture, but there are also a few landless and day labourers. The majority of the villagers have an income from wheat production and livestock keeping. The region is denoted as 'backward' in terms of the low rate of electrified households and female literacy and a high rate of Scheduled Castes and Tribes (Bakshi et al. 2015:47) ${ }^{6}$ and has also suffered from droughts in recent years. Due to their isolation and small sizes, the villages were considered suitable for decentralised electricity supply. Correspondingly, solar micro-grids 7 were initiated from 2009 and onwards. ${ }^{8}$ The solar electricity systems deliver electric current, which households use for lighting purposes and for electrical appliances such as TV, fans and for charging mobile phones. Most mobile phones on the Indian market are Smartphones and our informants use them to connect to the Internet. The electricity is also used for public street lights in the villages. In one of the Indian villages under study (Narwara) the project supplies deep groundwater with solar driven water pumps delivered directly to taps in households.

For the energy services in the Indian Uttar Pradesh case the connected households pay a monthly fee based on consumption. People's access to water depends on the seasons and their resources and incomes are highly fluctuating. Local operators who oversee the maintenance of equipment have been trained in the villages, while repairs are conducted by external engineers. In the Uttar Pradesh case all the paid staff involved in the electricity supply were men. The villages have also established Village Energy Committees (VECs) that have the overall responsibility for the electricity project and collection of revenues. The VECs have about 10 members to ensure balanced representation according to caste and gender. Usually two-three of the members are women, but due to cultural restrictions on women's right to raise their opinion in public arenas, these women said they did not attend the meetings.

\footnotetext{
${ }^{6}$ The state of Uttar Pradesh is showing a rapid improvement in Human Development Indicators, but intra state inequality is high and some of the subdistrict of Bundelkhand in this area have lower scores than state average.

7 A solar micro-grid is a small-scale power grid that can operate independently and is energised by solar photovoltaic (PV) technology.

${ }^{8}$ The micro-grid in Rampura village was introduced by Solar AS in 2009. The micro-grid in Narwara was introduced in 2011 by and the Indian Ministry of New and Renewable Energy, the Indian Renewable Energy Development Agency and the Norwegian Agency for Development Cooperation (Norad).
} 
The Bamiyan area is a mountainous area situated approximately $3300 \mathrm{~m}$ above sea level in central Afghanistan. The villages are extremely isolated and the area is one of the poorest provinces of Afghanistan with little infrastructure and difficult terrain for agriculture (World Bank 2010). Wheat cultivation, livestock and carpet weaving constitute the main income sources in the villages. From 2005 the Norwegian Church Aid set up Solar Home Systems (SHS) 9 in several of the villages in the area. The SHS deliver electrical current to households for lighting purposes and sockets for electrical appliances such as TV, radio and occasionally mobile phones. In 2007 there was no internet access in the area. Each household has one portable solar lantern, light and sockets in two rooms and one light placed on the outside wall of the house. Because of the remote and impoverished locations, and because there were no existing consumer chains for repair and equipment, two people from each village were selected and trained as local solar engineers in cooperation with the Barefoot College in India. ${ }^{10}$ They local engineers were paid a monthly salary for their services by the communities. Norwegian Church Aid made an effort to ensure that several of the solar engineers they recruited were women (Standal 2010:91).

\section{Gender, household and the community}

Places are not just geography, and the influx of technology needs to be understood as interventions in a space of social relations. The introduction of modern energy services has the potential to provide new meanings of everyday life and place such as village and home. The preferred household composition in the studied villages in Uttar Pradesh is the patrilocal pattern of co-residence, where sons stay in the household when married, while daughters leave and move into their husband's home. Young newly married women are held in tight control through the purdah system. ${ }^{11}$ They are not supposed to leave the house except for toilet visits, and are usually thus relieved of the burdensome tasks of fetching firewood and water. Women are always subscribed to cover head and face when ever in the gaze of other adult men than their husband, and cannot speak in the presence of their father-in-law. Issues such as giving birth in hospital or as sex-selection abortions, which are said to occur frequently in the area, are under the control of the father-in-law. When women have borne children they enjoy higher social status and become subject to fewer social restrictions than before.

\footnotetext{
${ }_{9}$ Stand-alone photovoltaic power systems are electrical power systems energised by photovoltaic panels which are independent of the utility grid.

${ }^{10}$ For more information please see www.barefoot.org

${ }^{11}$ Segregation of the sexes by physical segregation such as confinement to the home and/or requirement for women to cover their bodies in certain dress codes.
} 
The gender relations and women's status are relatively similar in the two case study areas. Bamiyan women join the family of their husband and adhere to the same restrictions as in Uttar Pradesh. The most important difference between the two places is that in Afghanistan, the issue of control over women's bodies and sexuality has become extremely politicised after more than 30 years of conflict and Taliban rule (Moghadam 1994, RostamiPovey 2007).

In addition to the unequal power relations based on gender and age, people in India and Afghanistan are differentiated by social categories of class, caste or clan from birth to death. The majority in the Uttar Pradesh villages were Other Backwards Castes (OBC) which means that they are perceived as disadvantaged, and with few exceptions they all belonged to caste groups of similar caste status. From 1994 the Uttar Pradesh government reserved seats at rural level councils for both $\mathrm{OBC}$ and women, which have led to changes in the political power relations in the state (Kumar 2013:119). This provided lower-caste groups access to power, but the very diverse entity of the OBC group in terms of caste, size and wealth has perpetuated inequalities within this group. According to the villagers, differences in their community were on economic terms rather than caste. The more affluent of the villagers we met belonged to the Yadav caste (also OBC). However, caste or financial situation did not seem to exclude families from having obtained electricity connection. The connection rate was $67-80 \%$. Further we found little differences in the way caste interacted with gender norms in terms of freedom of movement or access to benefits as the villages were so homogenous. However, we found that the position of women in terms of age and status as wife/ or as born into the family mattered greatly. The villages in Bamiyan were all Muslim belonging to the Hazara community. ${ }^{12}$ Here all households where initially part of the project, but due to return migration of refugees some households did not have access to solar energy, making new (and perceived unjust) divisions in the villages. Notably, the networks of women in the local village councils were composed across clan or class lines, contrary to the political networks of the men.

\section{Women's role in the energy supply: Engineers or end users?}

The training of women as solar engineers in the Bamiyan project challenged the traditional gender norms of women. After experiencing women solar engineers working on implementation and maintenance of the SHS all the men informants said that this had changed their perspectives on women's abilities and role in society. In their words this further inspired ambitions for the education of their daughters to something beyond just

\footnotetext{
${ }^{12}$ An ethnic group adhering to a form of Shia Islam.
} 
marriage and motherhood (Standal 2010:94). The local women solar engineers were also considered to be 'natural' members of their women village councils (ibid). This result indicates that electrification projects, when conducted in ways that include women as engineers rather than only as end-users, may contribute to challenging established gender ideologies. In comparison, the projects in Uttar Pradesh were set up in a conventional way with no particular strategy to include women in management and operation, and as a result, only men became involved as staff and were active in the Village Electrification Committees. We will discuss the significance of the two different strategies for electrification when having presented the empirical material further.

\section{Effects of electricity on women's care work practices}

Because women's responsibilities are inside the home where the lights were installed, people tended to relate the solar electricity to women's care work as wives and mothers. Most households had placed one of their light bulbs in the cooking area ${ }^{13}$ and the women expressed that cleaning, cooking, childcare and doing handicrafts now was more convenient. The women also felt that the time available for doing care work in the evenings was extended with electricity, because due to smell, cost and fear of accidents, kerosene would only be used for a short time. The role of motherhood was frequently brought up in relation to the effects of electricity, and narratives where told of how electricity made it easier to comfort children with nightmares or in need of toilet visits compared to the former situation when they depended on kerosene for lighting. Moreover, several of our informants complained that before the introduction of solar electricity their care work responsibilities had left them sleep deprived, due to their responsibilities for preparing traditional food and performing religious rituals early in the morning combined with taking care of young children's needs in the night. Electric light was perceived by them as providing better quality of sleep because comforting and nursing children at night would be easier and faster.

\section{Electricity's effect on family and marriage}

In Bamiyan, Afghanistan, people said that the improved visibility provided by electric light reduced the risks of accidents in the home. Some reported that before electricity's arrival, they had sometimes unwillingly stepped on children and broken their bones in the confusion

\footnotetext{
${ }^{13}$ In Uttar Pradesh, cooking was often done in the courtyard of the houses. It was a common perception that the implementation of the light and the water benefitted the daughter-in-law the most, as this was 'her area' of responsibility.
} 
of darkness and screaming babies. The increased visibility also helped to ensure that the food was not raw or overcooked when being served. Because of this opportunity to provide meals of better quality, women said electricity positively affected their esteem in relation to their husband and family-in-law. Both women and men said that the arrival of electric light had improved their marriage relationships, because the women's responsibilities were done adequately and more efficiently, causing less annoyance and complaints from the husband and the extended family. Some even said that electricity's positive effects on women's opportunities to provide care work had led to decreasing domestic violence:

...earlier the men often beat the women. The electricity has changed this, because earlier when the children cried in the night or wanted something this took more time to do in the dark. The men got angry and impatient. Now this takes shorter time and the women can prepare things (Standal 2010:85).

The positive effect on the marriage relationship was also connected to women's responsibilities as mothers. Many Bamiyan women gave accounts of how comforting and nursing their children more easily and rapidly with the aid of electric light, reducing the risk of violence from their husbands. The issue of domestic violence was never articulated in Uttar Pradesh, but the account of a young woman revealed that lack of good quality light may induce violence also from the women's side. Previously, she would sometimes get so tired of trying to soothe her two-year old child in the night that she ended up beating him so he would be quiet. After the introduction of electric light the boy would calm down quickly after the light had been turned on. Also with her second child, a five month baby She said she experienced fewer problems at night due to the electric light, which gave her a greater sense of accomplishment as a mother.

As these examples illustrate, the duties of wives and mothers can be related to domestic violence. Because violence is a sensitive matter and potentially undercommunicated during interviews, we cannot establish whether domestic violence occurs more often in Afghanistan than Uttar Pradesh, but there are signs that practical solutions (such as electric light) that help every-day life to may reduce the risk of violence. However, electric light does not change the norms that cause the hardship in the first place.

\section{Electricity's effects on social life and access to communication and information}

The introduction of light provides a qualitative shift with regard to interactions in the family, which also indirectly influences women's care work practices. Communication, relaxing and entertainment with TV, radio and mobile phones reorganize social life and brings a new 
quality of life. Because solar electricity provides light throughout the evening and night, the hours of the day became extended. Extra time in the evening was said to give more opportunity to talk together, watch television and, spend time with family or neighbors and more time and flexibility for women to do their chores.

\section{Light, happiness and socialising in Bamiyan}

A frequent narrative in Bamiyan was how the light brought happiness of mind and that this strengthened the family (Standal 2010:80). During the harvesting seasons, many family members work in the fields during daytime. Before electricity's arrival, the daily routine would only allow for meals and work and very little time for socialising among family members. When electricity was introduced the family and neighbours would spend more time together in the evenings which was said to improve well-being of all family members. Women pointed out that this had positively affected their decision-making power in the family. The new patterns for socialising also gave them more opportunities for networking with other women:

Everything is lighter now. When we come home from work the men are going to other families' houses and sit there. And the women do the same. The women go to other women's houses discussing and talking together. Before everything was dark (Standal 2010:79).

Bamiyan women seemed relatively free ${ }^{14}$ to move around in the villages, and many said that due to the portable solar lanterns, they could move more safely around the village at night to milk livestock and wash clothes (Standal 2010:61).

\section{The politics of access: Enjoying television, phones and Internet in Uttar Pradesh}

People in Uttar Pradesh were equally enthusiastic regarding electricity's impact on social life, and here, electricity's social purposes were particularly highlighted. Our informants appreciated the access to television programs and the Internet (Smartphones) and how this provided the possibility to be connected to the outside world through news, cricket matches and Indian soaps. The use of fans was also said to make social life more comfortable in the summer heat. The television set would often be on during daytime, and in Narwara the time saved by not having to fetch water would be used watching programs and looking after small

\footnotetext{
14 This issue is complex and factors such as age, company and not least size of village, in addition to moral codes such as purdah and pusthunwali, are important for women's mobility in Afghanistan, Pakistan and India.
} 
children. However, women's access to television and mobile phones was also restricted as these items were (most often) under men's ownership and control. Some men also explicitly said that certain programs would be unsuitable for women to watch, and in some families the daughters-in-law would be excluded from watching TV in the presence of the father-in-law.

\section{Connecting extended family networks}

In both case study areas, television and mobile phones did not just connect people to the rest of the world, also communities and families were connected together in new ways. They shared new 'world' information and their social life routines changed (Standal 2010). Connecting with family and friends played into the realm of care in important ways because extended networks are important social resources to individuals and families in everyday life as well as in times of crisis. During the civil war in Afghanistan, networks played a vital role to people's survival because families needed food and relocation (Rostami-Povey 2007:28). However, some people will not have access to information and communication either because their household cannot afford buying a television set or a mobile phone or, as in the case of Uttar Pradesh, because watching certain programmes is considered unsuitable for women. In In comparison, the Afghanistan informants did not mention that certain television programs would be unsuitable for women. ${ }^{15}$ Rather, Bamiyan women themselves pointed to television as a channel for obtaining information about women's rights. It was also here that electricity and lanterns were said to provide women with increased mobility in their neighbourhood at night, reflecting that such mobility is actually an option.

\section{Electricity's effects on care work related health problems}

Energy use has profound health implications, and health issues form a central part of women's care work. Globally, lack of modern energy constitutes the fifth important risk factor for disease in developing countries due to cooking, lighting and heating with traditional fuels. Indoor air pollution is produced by the burning of fossil fuels (e.g. kerosene, wood, animal dung) and causes child pneumonia, lung cancer, chronic pulmonary problems and low birth weight (Akbar et al. 2011). Women and children who are the groups who tend to spend most time indoors are particularly exposed to these risks. In addition the heavy loads of carrying firewood and water can lead to spinal injuries, pregnancy complications, premature births and maternal mortality (ibid, Matinga 2010). These tasks constitute important parts of women's care work and also women's self-care, because they may deplete women's bodily health (Elson 2005:8).

15 The issue of exclusion from watching television was only brought up during the interviews in the Uttar Pradesh case. 
In the study areas, the provision of solar electricity did not provide energy suitable for cooking and heating, but the new light had health benefits in several ways. Kerosene light emits toxic particles whereas solar light is clean. Moreover, the increased visibility which reduced the risk of rawness of cooked food was said to diminish infectious diseases. In Uttar Pradesh snakes and scorpions are highly venomous, which the electric light (and street lights) made it easier to spot. In this area many used the electric fans to limit mosquitos, which bring Malaria that cost families medical expenses and loss of agricultural labour.

\section{Health benefits of solar driven water supply}

In the village that received solar driven water supply in the Uttar Pradesh case (Narwara) women's physical burden was radically reduced. Previously they had spent four hours per day carrying water, taking two trips each day because of the weight load. After electrification they enjoyed having water taps at home. They would spend this reduced time on being with their children or relaxing with other family members. In their own opinion, the relief from the burden of collecting water was an improvement in life quality as much as improvement of health. In addition, electricity was also used for testing the quality of the water in this place, which eliminated the need to boil drinking water. The most significant and positive health effect from electricity was the simultaneous introduction of water pumps and taps in the village in Uttar Pradesh, whereas in the other places the effects on health were rather limited.

In Bamiyan, without such testing equipment and with a poorer water quality, boiling water was still necessary. This is a time-consuming task in itself and requires the collection and use of firewood. ${ }^{16}$ According to women we met, the responsibility of the family's energy needs was a heavy burden. One of our Afghan informants ${ }^{17}$ explained that women spent a lot of time and effort gathering fuel for the winter, but because of wood scarcity children became seriously ill during cold winters. Further, there was no healthcare available (Standal 2007:73). When being constrained from fulfilling these care work obligations, they expressed sorrow and powerlessness. The most common focus of modern energy provision has been to provide electricity for light and mobile phone charging, but in the studied areas such provision did not alleviate the burden of collecting firewood or reducing the main cause for indoor air pollution.

\footnotetext{
${ }^{16}$ In Bamiyan, Afghanistan, there was a lack of trees for firewood so people relied on a local bush and animal dung. Finding enough fuel was difficult as the bush was becoming scarcer and parts of Bamiyan were still covered with landmines from the Soviet occupation (Standal 2010:43).

${ }_{17}$ From neighbouring Daykundi province.
} 


\section{Electricity's effect on income, decision-making and dowry}

Electricity sometimes had a positive effect on women's income, and there is overlap in smallscale livelihood activities and women's care work. In Bamiyan the provision of light had doubled many households' income, because it extended the time for carpet-weaving performed by women and children. On the household level, the increased income enhanced by the carpet-weaving meant that their nutritional intake had increased considerably and many prioritised buying school material for their children to encourage education. Several also attributed improved marriage relationships to the improved income opportunities, because poverty was considered as 'the root to all bad things' (Standal 2010:82).

In Uttar Pradesh electricity had less effect on livelihood activities, because agriculture constitutes the main source of income and the solar electricity was not used for this purpose. One exception was Leela, a woman sewing and repairing clothes in her village. She had doubled her income extending the working hours in the evening by the use of electric light. She had however, felt the need to reduce her working hours after the birth of her second child, but was hoping to increase it again when the child was older.

\section{Income, ownership and decision-making}

Women's opportunities to make an income did not always translate into full decision making power in terms of how the money should be spent. The income of the women solar engineers in Bamiyan was seen as a family resource where individual gains belonged to all members (Standal 2010:65). According to custom, Bamiyan women are supposed to have a say in the allocation of money within the household, but in practice women (and children) doing the carpet-weaving did not seem to have an individualised right to the earnings they toil to make. Leela's income from sewing in Uttar Pradesh was partly used for personal consumption and for her children, but she was regularly asked to provide parts of her money to the joint family to cover unexpected expenses. She nonetheless concluded that the income had elevated her status in the household and partly provided increased economic independence and selfesteem. However, to the vast majority of the women in the two case study areas, ownership to land and houses is not an option. Such assets usually belong to the oldest man in the household, who also pays the electricity bill, which affirms men's position as the provider. Further, important decisions concerning medical cost on maternal and child health might be out of reach to many women regardless of income and access to electricity. Even if healthcare is available, such as in Uttar Pradesh, the cultural expression of knowledge places decisions on such matters as a prerogative of fathers-in-law and not the mothers themselves. Contrary to the common pattern in India where women return to their mother's house in the event of 
giving birth and during the first period of maternity, the practice in Uttar Pradesh is that her husband's family safeguards women and children.

\section{Predicaments: Dowry and the household economy ${ }^{18}$}

The issue of livelihood and energy is further complicated by the inflation of dowry into almost all social groups in India. The practice of dowry is coupled with households moving towards a modern lifestyle, meaning that electricity spurs consumption also in terms of marriage gifts (Wilhite 2008:78). As many families in Uttar Pradesh only have economic means for subsistence, dowry has become a pathway to heighten families' assets. Typical wedding gifts are TV, fans, and special versions of air coolers in addition to larger gifts such as motorcycle and cash. Wedding expenses are a constant worry for Indian families, and the social and material costs drive people into despair and poverty (Krishna 2011). This also means that income in the household is expected to be used for dowry, which in the long run has detrimental effects on families, and especially on women who according to our informants have to undergo the practice of sex-selective abortions. ${ }^{19}$

In sum, although the arrival of light increased women's opportunities for producing an income which served to level their esteem in the family, they did not have full control over how the money should be spent. In addition, the inflation in electricity-related artefacts as dowry in Uttar Pradesh poses a risk of strengthening patriarchic values that see the female gender as inferior to male gender.

\section{Discussion: Expectations, empowerment and the social value of women's work}

The provision of modern energy solutions in the presented case-studies offered women benefits in terms of improving the quality of their care work, enhancing some of their income generation and to some extent reducing the likeliness of domestic violence. These shifts increased their safety, comfort and convenience and also their status as wives and daughtersin-law. Their social resources were also strengthened through the improved communication with the outside world. Tenhunen (2014:41) have similar findings from West Bengal, were access to mobile phones provided several women with support from their natal families in difficult times. Electricity also reduced health risks and had positive effects on girls'

\footnotetext{
${ }^{18}$ In several Afghan communities the mahr or toyana (bride price) - a monetary transaction from the groom's family to the bride or her family is common practice. Unfortunately we have no information on how implementation of electricity has affected this.

19 The informants claimed that ultrasound sex-screening and abortion usually would take place after the birth of two consecutive daughters and was a decision made by the father-in-law.
} 
education However, in our Indian case, women's agency and decision making power was not strengthened in the electrification process. Quite the contrary, the channeling of more resources through the dowry system after electrification, can be said to reinforce the patriarchy and structures of inequality. The burden of dowry also influences the rate of sexselection abortions and produce skewed sex ratios, which further reinforce gender inequality (John 2011).

The Afghanistan case was different in that men in Bamiyan expressed that they had come to value women's abilities higher than before due the introduction of woman solar engineers. We suggest that this shift was partly linked to the process in which women were included as engineers, and the possibility that women-targeted interventions may have a transformative potential to change gender relations merits further attention. But also here, women's economic autonomy and material endowments continued to be severely limited after electrification due to socio-cultural practices discriminating women. Women had limited decision making power on how their income should be spent and they were restricted from accumulating long term resources (material endowments). The same tendency, that electricity provide women with opportunities in the short run but not endowments in the long run, has been observed in Zanzibar, Tanzania (Winther 2008), and in the Sunderban Islands in West Bengal, India (Winther 2014).

\section{Empowerment and the burden of responsibilities}

The expectation that women primarily deliver care work deserves additional comment. The presented narratives of how electric light help women when nursing hungry infants and avoiding serving raw, harmful food indicate that women gain increased confidence in how they perform their most important designated role and identity in these contexts: as wives, daughters-in-law and or mothers. The provision of energy opens up new space for women to 'deliver' on the expectations of mothering and marriage, which spurs a sense of psychological empowerment. Bandura denotes this state as a feeling of 'self-efficacy', which is contingent on an individual's belief in one's own capabilities (Bandura 1977). The sources of self-efficacy are based on mastery experience of earlier achievements, and are also related to the expectations of significant others.

Despite electricity's positive impact on psychological and social power it does not extend women's empowerment into the realms of making strategic life choices. This is because women's care work enforces women's economic dependency and hence care work reinforces patriarchy and entrench traditional hierarchies of power that denies women their agency and choice. Further, inability to influence events and social conditions that 
significantly affect one's life can give rise to feelings of futility, despondency and anxiety (Bandura 1977). This can be illustrated through the different expectations women have to conform to being a young mother at the power of parents-in-law and husband. There might thus be limits to the psychological empowerment associated with performing one's role as expected when this role per se involves subordination.

Henrietta Moore (1994) elaborates on this process which concerns identity formation by showing how previous experiences and rewards (or punishment) in one's social surroundings make people invest in some subject positions and not in others. To the women in the studied cases, electricity helped them meet basic needs of sleep and water and avoid frustration and violence. Electricity nurtured their identity as care workers, but the new technology did not affect the socio-cultural factors that produced discrimination against women.

If modern energy provided women with income this reproduction of women's role as care workers and devaluation thereof could potentially be balanced, both in terms of enhancing economic independence and decision making power, but also by gradually changing common perceptions of women's abilities beyond being wives and mothers. An example can be found in a women's Self Help Group project in Jharkhand, where electricity had been introduced for livelihood generation. ${ }^{20}$ The women in the Self Help Groups said that the income they made was at their own personal disposal and that they felt an improvement of status by acquiring resources to support their families. Still, they had to negotiate help with childcare when working, which made them work long hours with erratic and irregular incomes, such as the case of Leela in Uttar Pradesh. Personal finances from microcredit and savings were said to be especially important in times of crisis, as economic independence at such time would mean that the women themselves could make priorities and decisions. On the other hand, Bamiyan women rejoicing over being able to wash clothes in the night or Indian women earning an income, do not safeguard them from greater responsibilities than they realistically can manage. In contrast, the women trained as local solar engineers found their greatest sense of accomplishment and respect, not in their new income, but in the role as technologically skilled women delivering important resources to their community.

\footnotetext{
${ }^{20}$ The data material are gathered by Karina Standal in relation to the PhD project: The Impact of Solar
} Energy on Rural Women in India, Centre for Development and the Environment, University of Oslo. 


\section{Power, policy and energy as development}

The introduction of new technological innovations such as electricity tends to be perceived as neutral, unthreatening and the bedrock of progress (Crewe \& Axelby 2013:150). In reality, technological development is always entangled in ideological discourses of morality, culture and politics both within the spaces of development institutions and also the communities in which they are implemented. These various discourses also include categories of women and men and adhering gender norms. Women who have 'traveled' the path of marriage, motherhood and age have legitimacy to act beyond the normal gendered identities by speaking in public or changing dress codes, and still require respect instead of social sanctions (Lamb 2000, Wakefield 2004:23, Standal 2010:97). These social practices of who is 'out of place' and who is 'in place' according to the contextual category of woman, may potentially be challenged and altered by new invented spaces brought on by technological innovations and development intervention. For the women 'beneficiaries' in this study, the new technology represented a resource that both challenged and reinforced existing gendered hierarchies and inequalities, which has also been observed in other similar contexts such as West-Bengal (Winther 2014:58).

National policies and local conceptualisations of the electricity interventions also affected the outcomes in relation to transformation of gender norms. India has experienced rapid socio-economic changes recent years, which have been followed by a growing visibility of women in the public domains of education, work and politics. Also in rural politics, women have been given reserved seats in village councils. However, these changes have not been evenly distributed. Our informants in Uttar Pradesh expressed a growing desire for 'development', which made most of the villagers embrace the solar energy projects as they had lost faith in the state providing connection to the main grid. Despite women's reserved representation in rural councils, the women in the villages had no network that could actively take part in the implementation project. In line with the donor's approach, the benefits of the project became limited to helping women in their domestic role. In Afghanistan the project arrived in a context of nation-building that also took place in rural areas. Our informants saw the solar electricity as a positive continuation of the rehabilitation and development of their communities. Through rural projects women where activated and reserved seats in local village councils (Barakat et al 2006, Standal 2008:99). These councils provided the women with strong networks that made use of the opportunities provided by solar electricity for gathering information about women's rights through Afghan and Iranian TV and radio. The training of women as solar engineers created powerful role models for the women networks (Standal 2008:59). 
Within current development policies on energy, the framing of women appears strikingly similar to the ones observed in Uttar Pradesh. Despite the (over-estimated) trust in women's agency within 'smart economics' (Chant and Sweetman 2012), ${ }^{21}$ energy policies tend to portray women in their role as mothers, wives and passive end-users of new services. Consider the following presentation of men and women in this quote taken from the current website of the international initiative 'Sustainable energy for all' (SE4ALL):

Energy can be used to support businesses and achieve greater prosperity. A farmer who irrigates his fields can double the size of his crop, feed his family, and earn a living. A sewing machine and a light to work from at night can enable a woman to generate extra income for her family (SE4ALL)22

With some exceptions (e.g. the ENERGIA network, ESMAP, Norad), energy sector policies and practices continue to regard women in the South as the locus for reproduction. In energy interventions they are regarded as important end-users, as reflected in cooking stove investments, which are certainly needed. ${ }^{23}$ However, women are not generally included in the process and politics of forming new energy solutions. In addition, what the presented analysis has highlighted and feminist theorists have long argued, there is a lack of focus on the unequal relations and structural barriers that hinder women's empowerment.

\section{Conclusion}

Drawing on the concepts of empowerment and care work this article shows how modern energy provision open up new opportunities for women and potentially create opportunities for new gender discourses that benefit women's empowerment. We have highlighted the way new energy services provide time for prioritising and performing care work in a qualitatively better way, which translates into higher sense of self-efficacy. In addition the energy provides social power through opportunities for information and connection to extended family due to mobile phones and TV, and also health benefits, which is a prerequisite for development and empowerment. However, as illustrated by the case of Uttar Pradesh, the provision of energy may also undermine women's agency by upholding and perhaps even strengthening subversive structures such as patriarchy and dowry. This is a reflection of energy sector policies and practices, which continue to regard a gender focus as a question of women only

\footnotetext{
${ }^{21}$ The 'smart economics' promoted by development organisations, governments and businesses (Chant and Sweetman 2012) presents women as central in the households' coping strategies, but such initiatives may put women at risk of being (further) exploited.

${ }^{22} \mathrm{http}$ ://www.se4all.org/our-vision/our-objectives/universal-energy/

${ }^{23}$ For an interesting discussion of this please see Crewe, Emma. 1997. 'The Silent Traditions of Developing Cooks.' In Grillo, R. \& R.L. Stirrat (eds) Discourses of Development,
} 
being important end-users and the locus for reproduction. Therefore, women are not generally included in the process and politics of forming new energy solutions. In Bamiyan however, the training of women as solar engineers seems to have made the provision of modern energy work as a catalyst for challenging perspectives of women's abilities and their participation in public and private decision-making. This was expressed in men's accounts of how they have come to regard women after the introduction of electricity and also by women who said that they had gained increased possibilities to raise their opinions in the household. We argue that only by focusing on the unequal relations and structural barriers that hinder women's empowerment at the onset of planning and implementation is it possible to avoid the tendency that energy and development initiative are reinforcing women's traditional role in patriarchal and suppressive structures. While we do not expect that gender equality can be solved through energy alone, we argue that more ambitious energy policies and practices, which take power relations into account, and which include women in the process as was done in Bamiyan, Afghanistan are needed. This could lead to substantial results in promoting men and women's equal status and conditions for living.

\section{References}

Akbar, Sameer, Barnes, Douglas, Eil, Andrew and Anastasia Gnezditskaia (2011), 'Household cookstoves, environment, health and climate change: A new look at an old problem'. World Bank. Internet access: http://wwwwds.worldbank.org/external/default/WDSContentServer/WDSP/IB/2011/07/20/000386194 201107 20022733/Rendered/PDF/632170WPoHouseooBoxo361508BoPUBLICo.pdf Date:9.3.2015

Bakshi, Sanchita, Chawla Arunish and Shah, Mihir (2015), 'Regional disparities in India. A moving frontier', Economic \& Political Weekly, Vol. L, No. 1, pp. 44-52.

Bandura, Albert (1977), 'Self-efficacy: toward a unifying theory of behavioral change'. Psychological Review, Vol. 84, No 2, pp. 191-215.

Barakat et al, S. 2006. Mid-term Evaluation Report of the National Solidarity Program (NSP), Afghanistan. Post War Reconstruction \& Development Unit, University of York.

Chant, Sylvia and Sweetman, Caroline (2012), 'Fixing women or fixing the world? "Smart economics", efficiency approaches, and gender equality in development'. Gender \& Development, Vol. 20, No. 3, pp. 517-529.

Crewe, Emma and Simon Axelby (2013), Anthropology and Development Culture, Morality and Politics in a Globalised World. Cambridge: Cambridge University Press. 
Elson, Diane. 'Unpaid Work: Creating Social Wealth or Subsidizing Patriarchy?' Paper presented at the Forum on Social Wealth, Political Economy Research Institute, University of Massachusetts, December 1. 2005.

England, Paula (2005), 'Emerging Theories of Care Work', Annual Review of Sociology, Vol. 31, No 1, pp. 381-399.

Friedmann, Jonathan (1992), Empowerment. The Politics of Alternative Development, Cambridge: Blackwell.

Gertz, Clifford (1973), 'Interpretation of Cultures', New York: Basic Books.

John, Mary E. (2011), 'Census 2011: Governing Populations and the Girl Child', Economical Political Weekly, Vol. 46, No 16, pp. 10-12

Kabeer, Naila (2001), Discussing Women's Empowerment: Theory and Practice, SIDA studies, Stockholm.

Krishna, Anirudh (2010), One illness Away. Why People Become Poor and How they Escape Poverty, Oxford: Oxford University Press.

Kumar, Satendra (2013), 'Inclusion of Excluded Groups Through Panchayati Raj: Electroral Democracy in Uttar Pradesh', in Kenneth Bo Nielsen; Uwe Skoda \& Marianne Qvortrup Fibiger (eds), Navigating Social Exclusion and Inclusion in Contemporary India and Beyond: Structures, Agents, Practices. London: Anthem Press, pp. 119-135.

Lamb, Sarah. (2000), White Saris and Sweet Mangoes. Aging, Gender, and Body in North India. Berkeley: University of California Press.

Matinga, Margaret. N. (2010) "'We grow up with it.” An ethnographic study of the experiences, perceptions and responses to health impacts of energy acquisition and use in rural South Africa.' PhD. Diss. Univeristy of Twente.

Moore, Henrietta L. (1994), A Passion for Difference: Essays in Anthropology and Gender, Cambridge: Polity Press.

Rostami-Povey, Elaheh (2007), Afghan Women. Identity and Invasion. London, Sed Books.

Sen, Amartya Kumar (1985), Commodities and Capabilities. Amsterdam: North-Holland.

Sharma, Ursula (1986), Women's Work, Class, and the Urban Household: A Study of Shimla, North India

Standal, Karina (2010). Giving Hope and Light in Afghanistan. Enlightening Women's Lives with Solar Energy. Lampert Academic Publishing 
Tenhunen, Sirpa (2014), 'Gender, Intersectionality and Smartphones in Rural West-Bengal'. In Nielsen, K.B \& A. Waldrop (eds) Women, Gender and Everyday Social Transformation in India. Anthem Press: London, pp. 33-47.

Wakefield, Shawna (2004), 'Gender and Local Level Decision Making. Findings from a Case Study in Panjao,. Afghan Research and Evaluation Unit', Internet access:

http://www.areu.org.af/Uploads/EditionPdfs/435E-Local\%2oDecision\%20Making\%2oPanjao\%20CS-web.pdf Date: 9.3.2015

Wilhite, Harold (2008), Consumption and the Transfomation of Everday Life: A View from South India, New York: Palgrave Macmillan.

Winther, Tanja (2008), The Impact of Electricity. Development, Desires and Dilemmaes, New York: Berghahn Books.

Winther, Tanja (2014), 'The Introduction of Electricity in the Sundarban Islands: Conserving or Transforming Gender Relations?' In Nielsen, K.B \& A. Waldrop (eds) Women, Gender and Everyday Social Transformation in India. Anthem Press: London, pp. 47-61.

World Bank (2010), Poverty Status in Afghanistan. Internet access: http://siteresources.worldbank.org/AFGHANISTANEXTN/Resources/305984-1264608805475/67396191286210806756/AFPovertyReport.pdf . Date: 20.03.2015

World Bank (2011), World Development Report 2012: Gender Equality and Development. Washington DC: World Bank Group. 